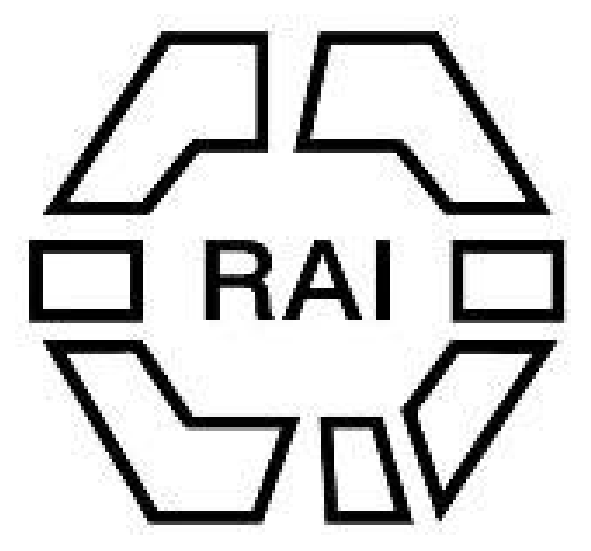

\title{
WILEY
}

\section{A Legend of St. Brigid}

\section{Author(s): Elizabeth Andrews}

Source: Man, Vol. 22 (Dec., 1922), p. 187

Published by: Royal Anthropological Institute of Great Britain and Ireland

Stable URL: http://www.jstor.org/stable/2839430

Accessed: 08-05-2016 04:59 UTC

Your use of the JSTOR archive indicates your acceptance of the Terms \& Conditions of Use, available at

http://about.jstor.org/terms

JSTOR is a not-for-profit service that helps scholars, researchers, and students discover, use, and build upon a wide range of content in a trusted digital archive. We use information technology and tools to increase productivity and facilitate new forms of scholarship. For more information about JSTOR, please contact support@jstor.org.

Royal Anthropological Institute of Great Britain and Ireland, Wiley are collaborating with JSTOR to digitize, preserve and extend access to Man 
many measurements (estimated : L. 191, B. 147, H. 120), appears to be the largest cave skull yet found and forms a connecting link between this type and the Boskop skull. Like the latter, the skull from Coldstream is distinguished by the great thickness of the bone, amounting to 11-12 millimetres over a large part of the vault. A study of the outlines of the crania made by the use of a Lucas's Orthograph show that the skulls from the cave burials and the Bushmen differ from the Hottentots in the greater flattening of the vault and of the occipital region and in a greater development of the parietal region. In both the frontal region is poorly filled out. It is possible that the greater development in regions corresponding to the sensory association areas of the brain may be associated with the superior artistic attainments of the Bushmen.

While there is a certain general resemblance in outline between the Bushmen and the Hottentot crania, the feature is less noted in specimens of the latter from the north of the Orange river, and it may well be that this is due to admixture of Bushman blood by the seizure of the females as the Hottentot tribes worked their way southwards, as is described by the historians of Cape Colony. On the other hand the Hottentot tribes to the north and east may have, to a considerable extent, intermarried with Bantu-speaking peoples of the central group.

F. C. SHRUBSALL.

\title{
Ireland : Folklore.
}

Andrews.

A Legend of St. Brigid. By Elizabeth Andrews.

In further reference to the spring feature of St. Brigid* I am indebted to 100 Miss Delap for a curious legend from Valentia Island which, with fine disregard of chronology, makes St. Brigid a friend of the Virgin Mary. It is said that when the Virgin was shy about facing the congregation in the Temple, St. Brigid procured a harrow, took out the spikes and, putting a candle in every hole, placed it on her head, walked up before the Virgin and escorted her down again. According to another version, which it is believed came from the north of Ireland, it was a hoop with lighted candles which the Saint wore as she danced up the aisle before the Virgin and down again. For this service St. Brigid's Day is the eve of Candlemas, or the Purification of the Virgin.

ELIZABETH ANDREWS.

\section{England: Sociology.}

\section{REVIEWS.}

The English Village, the Origin and Decay of its Community. An Anthropological Interpretation. By H. J. E. Peake. London: Benn Bros., 1922. Pp. 251. $22 \times 15 \mathrm{~cm}$. Price $15 \mathrm{~s}$.

The author's well-known position is that anthropology includes the study not only of nature-folk and of prehistoric times but of ourselves and our social organisms. Whereas history in its present state of development confines itself too much to the written document, anthropology may study the living organism or its works and their distribution. Of the value of this attitude for the refreshing of thought there can be little doubt and it holds within it the potentiality of a more truly scientific sociology and social psychology for the future.

In the present work the author tries to argue out the origins of the village and its agricultural community as it existed in early mediæval times. This leads him to attempt a short but balanced account of the early racial history of Europe as well as of early social organisation. In this last it is interesting to note that he has shaken himself free from the traditional view that there is an almost inevitable sequence from hunting to shepherding and from shepherding to agriculture.

\author{
* See MAN, 1922, 34, p. 51 .
}

[ 187 ] 